Julia Kiestrzyn

\title{
ODKRYWANIE BOGA
}

\section{INTERPRETACJA PIEŚNI O BLASKU WODY}

Woda jest uzdrowicielką, źródłem życia i zdrowia. Każdy żywy organizm rozpoczyna w niej swoje życie. Jest cudownym lekiem na wiele schorzeń, o czym pisał, między innymi, niemiecki lekarz Kneip w książce Moje leczenie wodą, w której stwierdził, że każdy kontakt z wodą to dodatkowa minuta życia. Od wieków znane są historie o cudownych, leczniczych źródłach, o wytryskiwaniu wody w miejscach objawień, a także o objawieniach, które miały miejsce w pobliżu wody, czyli w miejscach czystych, wolnych od złej energii. Szczególnie w wodzie „żywej” - płynącej upatruje się cudownych i leczniczych właściwości.

Woda zajmowała i zajmuje ważne, a często nawet kluczowe miejsce w wielu religiach, wierzeniach i kulturach. Od wieków wykorzystuje się ją podczas przeprowadzania rozmaitych rytuałów. W czasach pogańskich czczono ją i uważano za świętość. W religii chrześcijańskiej używana jest do wielu czynności liturgicznych, między innymi, podczas udzielania sakramentu chrztu, a w wierzeniach hinduizmu zajmuje ważne miejsce jako święta rzeka Ganges, wcielenie bogini Gangi, w której zanurzenie według wyznawców tej religii, oczyszcza człowieka z grzechów, nieszczęść, ogólnie pojętej złej energii.

Woda ma udzielać łask, oczyszczać, uleczać z chorób, chronić przed wpływami szatańskimi i zapewniać bezpieczeństwo. Wierzymy w nią do dziś. Przecież to ona zapewnia życie i nie bez powodu Ziemia nazywana jest Błękitną Planetą. Woda obiega cały świat, całą przestrzeń. Płynie w każdej komórce, w każdej żywej istocie. Można powiedzieć, że łączy wszystkie organizmy, ponieważ wszyscy potrzebujemy jej tak samo. Jest twórczynią całej ziemskiej obfitości, a kiedy jej braknie, pojawiają się katastrofy. 
„Wodo, nie masz ani smaku, ani koloru, ani zapachu, nie można ciebie opisać, pije się ciebie, nie znając ciebie. Nie jesteś niezbędną do życia: jesteś samym życiem" - pisał Antoine de Saint-Exupery ${ }^{1}$.

Nad cudownością wody pochylił się także Jan Paweł II. Dostrzegł jej niezwykłość i życiodajność równoznaczną z boskością. Woda zainspirowała go do stworzenia Pieśni o blasku wody, którą napisał w roku 1950 jeszcze jako Karol Wojtyła.

Dla mnie jest to utwór wielowymiarowy i niejednoznaczny, ale przede wszystkim uniwersalny. Sam w sobie jest głębią - głęboką studnią, z której można zaczerpnąć mądrości i inspiracji do filozoficznych refleksji, do rozważań nad istotą życia. W moim odczuciu jest to utwór przede wszystkim o potrzebie rozbudzenia wewnętrznego życia, odkrycia w sobie Boga, o poszukiwaniu Go we własnym wnętrzu. Jest to także pieśń o poznawaniu, odkrywaniu tajemnicy bytu, tajemnicy istnienia. Przedstawione odkrycie Boga przez podmiot liryczny jest utożsamione ze swego rodzaju inicjacją, wejściem w nowy etap życia, osiągnięciem duchowej dojrzałości.

Nastrój Pieśni o blasku wody jest podniosły, a konstrukcja wyznaniowa, o czym świadczą słowa, w których ujawnia się obecność podmiotu lirycznego: „przyszłam”, „znalazłam”, powodujące silną indywidualizację tekstu. Konstrukcja wyznaniowa służy ukazaniu subiektywnego spojrzenia na świat. Wyraża autonomiczność, jednostkowość i niepowtarzalność człowieka. Podmiot liryczny ma rodzaj żeński, jest nim jakaś kobieta i chyba nie bez powodu, ponieważ w kulturze ludowej pobieranie wody ze studni było obowiązkiem właśnie kobiet.

Kobieta wydaje się prowadzić monolog. Nikt jej w utworze nie odpowiada, jednak w drugiej zwrotce ujawnia się, choć nie bezpośrednio, adresat słów: „pragnę, byś pozostał jak w zwierciadle studni”. Odbiorca wypowiedzi milczy, ale istnieje, skoro kobieta do kogoś mówi. Myślę, że adresatem słów jest Bóg i do niego są skierowane te bardzo osobiste i emocjonalne słowa. Bóg nie odpowiada mową, ale objawia się w wodzie jako blask i jest obecny w przeżyciach wewnętrznych kobiety.

Jan Paweł II upatruje Boga w wodzie, w świetle, w kwiatach i liściach, w człowieku, a nawet w spojrzeniu i jako spojrzenie, bo przecież oczy są zwierciadłem duszy, a duszą łączymy się z Bogiem.

W religii chrześcijańskiej oko jest symbolem wszechwiedzy i wszechobecności Boga. Powszechnie znane jest artystyczne wyobrażenie Boga przedstawionego jako oko opatrzności w równoramiennym trójkącie, symbolizującym Trójcę Świętą. Oko jest również ważnym symbolem w religii hinduizmu, gdzie symbolizuje czakrę trzeciego oka, której rozbudzenie prowadzi do otwarcia się na wyższą świadomość, czyli również na Boga tylko może inaczej rozumianego.

${ }^{1}$ Antoine de Saint-Exupery, Ziemia, planeta ludzi, Część VII: W sercu pustyni. Warszawa 1993. 
Niezwykłym wykorzystaniem chrześcijańskiego symbolu oka jest dzieło pochodzące z przełomu średniowiecza i renesansu - Stół Hieronima Boscha, przedstawiający ilustracje siedmiu grzechów głównych, mające charakter moralizatorski. Bosch na środku okrągłego stołu, który nie bez powodu ma kształt koła, symbolu nieskończoności, umieścił symboliczną postać tęczówki oka człowieka, a w źrenicy tej tęczówki Zmartwychwstałego Chrystusa. Inskrypcja pod jego postacią głosi: „On widzi wszystko”. To jedno zdanie mówi wszystko. Obrazuje wszechobecność Boga w życiu człowieka, prawdę, która się przed nim nie ukryje. Umieszczenie Jezusa w źrenicy sugeruje także centralną i najważniejszą rolę jaką Bóg powinien pełnić w życiu człowieka. Zgodnie z przekazem dzieła, w całym swoim postępowaniu człowiek powinien mieć na uwadze rozwój duchowy, oddalając się od grzechów, symbolicznie zbliżać do centrum, czyli do Boga.

W utworze Pieśń o blasku wody symbolikę oka i źrenicy wraz z motywem studni łączy pewna bardzo ważna cecha - okrągły kształt, przywodzący na myśl uro boros - staroegipski i grecki symbol przedstawiający węża z ogonem w pysku, który wciąż połyka siebie i się odradza, obrazując nieskończoność, wieczne odradzanie świata, podobnie do symboliki mitycznego Feniksa.

W Pieśni o blasku wody symbole o kształcie koła określają Boga. Wyrażają jego nieskończoność i wieczność. Symbolizują także czas kołowy, nazywany inaczej sakralnym, zgodnie z którym wszystko w naturze się odradza, zmartwychwstaje wciąż od nowa. W utworze odrodzenie duchowe jest udziałem podmiotu lirycznego, który odkrywając w sobie Boga, wchodzi w nowy, życiowy etap.

Symbolika koła w Pieśni o blasku wody to również obietnica duchowego odrodzenia człowieka po śmierci, a więc i jego nieskończoności. Jan Paweł II pokazuje w ten sposób, że doskonałość i wieczność Boga może być udziałem człowieka, jeśli otworzy się on na siłę wyższą, która wypełni nieskończoną miłością jego wewnętrzną pustkę. W obrazie kobiety, która przychodzi do studni zaczerpnąć wody, Jan Paweł II ukazuje wolną wolę człowieka. Jak zauważył Pico della Mirandola, znany włoski filozof doby renesansu: „Człowiek jest kowalem swojego losu”2, którą to maksymę znamy i powtarzamy do dzisiaj. Od człowieka zależy więc jak pokieruje swoim życiem, czy da sobie szansę na znalezienie w swojej duszy Boga.

Pieśń o blasku wody Boga ukazuje w przyrodzie jako całości i w każdym odrębnym bycie, tym samym pokazując, że każdy byt jest boskim cudem, dziełem stworzenia. W każdym życiu jest tchnienie Boga, co wprowadza do utworu filozoficzną refleksję na temat relacji człowieka z przyrodą, z otaczającym światem.

Karol Wojtyła jako papież zachęcał do życia w braterstwie z innymi stworzeniami, do szacunku do przyrody, którą to myśl zawarł już w Pieśni o blasku wody,

\footnotetext{
${ }^{2}$ Giovanni Pico della Mirandola, Mowa o godności człowieka, Warszawa 2010, s. 3.
} 
inspirując się filozofią franciszkańską. Podczas swojego pontyfikatu często apelował do ludzi, by zaczęto dbać o środowisko, szanować przyrodę:

Prawo, które zostało przez Boga wpisane w naturę i które można odczytać za pomocą rozumu, skłania do poszanowania zamysłu Stwórcy - zamysłu, który ma na celu dobro człowieka. To prawo wyznacza pewien wewnętrzny porządek, który człowiek zastaje i który powinien zachować. Wszelkie działanie, które sprzeciwia się temu porządkowi, nieuchronnie uderza w samego człowieka (...)

Piękno tej ziemi skłania mnie do wołania o jej zachowanie dla przyszłych pokoleń. Jeżeli miłujecie ojczystą ziemię, niech to wołanie nie pozostanie bez odpowiedzi! ${ }^{3}$

Te słowa, które wygłosił w Zamościu w roku 1999, oddają najpełniej szacunek jakim Jan Paweł II darzył przyrodę. Był znany z zamiłowania do podróży, zwłaszcza do górskich wędrówek. Głównym wykładnikiem jego pontyfikatu były pielgrzymki, dlatego też zyskał miano papieża pielgrzyma. Gdziekolwiek się pojawiał, cechowała go wielka pokora, szacunek do ziemi i wszystkich stworzeń, co wyrażało się w jednym z jego najważniejszych gestów, jakim było całowanie ziemi. Jan Paweł II niejednokrotnie podkreślał, że przyroda jest dziełem Boga, że jest z Bogiem scalona i ta myśl, te uczucia musiały mu już towarzyszyć i inspirować podczas pisania Pieśni o blasku wody, kiedy papieżem jeszcze nie był.

Snując refleksję na temat tajemnicy istnienia, Jan Paweł II łączy słowa z muzyką, ponieważ utwór, jak wskazuje tytuł, jest pieśnią, a więc utworem muzycznym. Muzyce od wieków przypisuje się niezwykłą, wręcz mistyczną rolę. Nie bez powodu mówi się, że ten, kto śpiewa, wielbi Boga dwukrotnie. Muzyka jest ważnym elementem w wielu religiach, wyznaniach, kulturach...

Grecy uważali muzykę za najdoskonalszą ze sztuk. Muzyka w ich kulturze odgrywała znaczącą rolę, między innymi, w poezji. Słowo współistniało z muzyką. Te dwie sztuki doskonale się dopełniały, razem stawały się dla słuchaczy niezwykłym przeżyciem duchowym. Muzyka służyła uwzniośleniu poezji.

Pieśń jest utworem lirycznym, a już sama nazwa rodzajowa „liryka” ma pochodzenie muzyczne. Oznacza pieśń śpiewaną przy akompaniamencie liry. Utwory poetyckie chętnie śpiewano, co miało nobilitować literaturę. Dobrze znanym jest mit o Orfeuszu, wybitnym śpiewaku i poecie, którego śpiew w wyjątkowy sposób oddziaływał na świat. Mity wspominają o cudownych właściwościach jego muzyki, która wpływała nie tylko na ludzi, ale i na przyrodę. Mogła uśmierzać huczące fale morza, sprawiać, że ku śpiewakowi pochylały się drzewa, a dzikie bestie za nim

\footnotetext{
${ }^{3}$ Jan Paweł II, Orędzie na XXIII Światowy Dzień Pokoju, n. 7.
} 
podążały jak łagodne baranki. Muzyka wpływała kojąco i łagodząco na wszystko, co groźne, złe, agresywne... Łagodziła zło, zamieniała je w dobro.

Muzyka ma także ogromne znaczenie i pełni bardzo istotną rolę w kulturze amazońskich Indian, ponieważ zgodnie z nauką szamanów, wszystkie poziomy egzystencji - zarówno materialne jak i niematerialne - posiadają swoją melodię, wibrację, rytm, nazywany przez nich icaro. Icaro jest esencją władzy szamana. Oznacza magiczną melodię mocy, przez którą można komunikować się ze światem duchowym. Szamani wykorzystują tę melodię do uzdrawiania chorych. Muzyka od zawsze łączy się więc w naszym pojęciu z życiem duchowym. Pobudza, inspiruje, wyzwala ekspresję uczuć, zdaję się być łącznikiem ze sferą sacrum. Myślę, że dlatego też Jan Paweł II, chcąc zainspirować do filozoficznej refleksji nad pięknem duchowym, cudem boskiego stworzenia i tajemnicą bytu, sięgnął właśnie po muzyczny gatunek literacki, jakim jest pieśn.

„Nie zdołam Cię całego przenieść w siebie” - to metafora obrazująca wielkość i niemierzalność Boga, który jest bytem wszechobecnym, niemożliwym do objęcia umysłem. Bóg jawi się w utworze jako będący ponad ograniczeniami, niemożliwy do zamknięcia w jakiejkolwiek przestrzeni. Dalsze słowa podmiotu lirycznego odzwierciedlają chrześcijański pogląd stworzenia człowieka przez Boga na swoje podobieństwo: „ale pragnę byś pozostał jak w zwierciadle studni”. Pragnieniem osoby mówiącej jest więc widzieć w sobie odbicie Boga, być zwierciadłem dla jego doskonałości. Przychodzi ona do studni zaczerpnąć wody, która jest metaforycznym obrazem zaczerpnięcia cudownej mocy Boga.

Szczególne znaczenie ma w utworze także motyw dzbana, który moim zdaniem obrazuje człowieka jako naczynie dla Bożej miłości i mocy. Dzban to pewna ograniczona przestrzeń symbolizująca ograniczoność człowieka, jego mierzalność, kontrastującą z wszechobecnością i niemierzalnością Boga. Człowiek, reprezentowany w utworze przez kobietę, nie jest w stanie zmieścić w sobie całego Boga. Jest jedną z wielu istot zamieszkujących ziemię i będących naczyniem dla boskiej mocy. Z tych słów płynie pokora i szacunek do świata, ponieważ wszystko co się na niego składa, jest odbiciem Boga, a więc jest pod jego opieką.

Porównując znaczenie motywu dzbana w utworze Pieśń o blasku wody z jego znaczeniem w innych tekstach literackich, nasuwa się skojarzenie z Balladyna - dramatem Juliusza Słowackiego. Niewykluczone, że Karol Wojtyła, który teatr kochał i znał doskonale, pomyślał właśnie o dzbanie, do którego Alina i Balladyna zbierały maliny, rywalizując o lepszą przyszłość. W dramacie Słowackiego nazbieranie dzbanka malin wiąże się ze wielką zmianą w życiu, ponieważ ta siostra, która pierwsza napełni dzbanek, poślubi króla, a więc zostanie społecznie wywyższona. Zyska bogactwo, pozycję i władzę. Podobnie, moment przyjścia do studni z dzbanem jest przełomowy dla podmiotu lirycznego w utworze Pieśn o blasku wody, ponieważ odnajduje on w głębinie studni Boga, który go napełnia, niejako 
nadając mu sens, a więc i nowe życie. Kobieta staje się innym człowiekiem, odkrywa w sobie moc. Blask Boga otwiera jej oczy na prawdę, a jest nią pustka w niej samej. Ogrom zdumiewającej i przytłaczającej pustki, która staje się dla kobiety przestrzenią poznawczą, przestrzenią kontaktu z siłą wyższą: „Tyle, tyle poznania znalazłam - ileż więcej niż dotąd!”.

Symbolikę dzbana można rozpatrywać, jednak od jeszcze innej strony - jako samoograniczanie się człowieka. Kobieta przychodzi do głębokiej studni tylko z dzbanem, naczyniem stosunkowo niedużym, a z pewnością zbyt małym, by zaczerpnąć duży zapas wody. Sama więc odbiera sobie możliwość sięgnięcia po większą ilość wody symbolizującej bożą moc. Myślę, że w tych słowach zawiera się jeden z najważniejszych późniejszych przekazów papieża: Nie bójcie się tajemnicy Boga. Nie bójcie się jego miłości. Jan Paweł II apelował do ludzi, by nie ograniczali się w czerpaniu miłości Boga i nie czuli przed nim lęku, ale otwierali na jego moc, poszukiwali go w sobie. Powtarzał to ludziom na całym świecie: „Nie lękajcie się! Otwórzcie, otwórzcie na oścież drzwi Chrystusowi! Jego zbawczej władzy otwórzcie granice państw, ustrojów ekonomicznych i politycznych, szerokich dziedzin kultury, cywilizacji, rozwoju. Nie lękajcie się! Chrystus wie, co jest w człowieku. Tylko On to wie!"4 - tak brzmią chyba jego najsłynniejsze słowa, które wygłosił podczas pontyfikatu i myślę, że Pieśń o blasku wody również jest przesiąknięta tą refleksją, która musiała być obecna w umyśle Karola Wojtyły jeszcze zanim został papieżem.

Woda w utworze roztacza światło - blask, który przywiera, który prześwietla oczy, przenika człowieka do głębi. Wydobywa się on z wody - żywiołu, dającego życie. „Blask” jest jednym z motywów należących do metaforyki solarnej, ma ona swoje głębokie ugruntowanie kulturowe, a sens motywu blasku można odnaleźć, między innymi, w Biblii. W Nowym Testamencie zacytowane są słowa Chrystusa, który mówi: „Ja jestem światłością świata, kto we mnie wierzy będzie żył na wieki” (J 8, 12). Światło w literaturze, czerpiącej z tradycji biblijnej, jest symbolem Boga, duchowości, bezcielesności i intuicji, czyli tego wszystkiego, czym Bóg jest - energią, która nie ma kształtu, której duch znajduje się w każdym życiu, którą wyczuwamy intuicyjnie, ale nie jesteśmy w stanie jej pojąć. Motyw blasku w pieśni Jana Pawła II łączy się również z myślą neoplatoników - z ideą claritas, która zakłada, że byt jest emanacją światła od bóstwa. Blask symbolizuje więc Boga, wyższy poziom bytu, który odbija się w każdym stworzeniu, którego światło spływa na wszystkie byty.

Blask to także wszechwiedza, otwarcie się na siłę wyższą, osiągnięcie duchowej dojrzałości. W takim znaczeniu występuje w kulturze hinduizmu, zgodnie z którą

${ }^{4}$ Jan Paweł II, Homilia wygłoszona 22 października 1978 roku podczas Mszy św. na rozpoczęcie pontyfikatu. 
blask towarzyszy człowiekowi podczas medytacji w momencie otwarcia czakry trzeciego oka, co jest przełomowym momentem dla praktykujących medytację, ponieważ wiąże się z osiągnięciem samorealizacji, połączeniem z Absolutem, co przekładając na naukę chrześcijańską, myślę, że oznacza właśnie odkrycie w sobie Boga. Blask, który w tym momencie wpływa przez czakrę trzeciego oka do wnętrza człowieka rozumiem jako zaproszenie do siebie Boga, otwarcie się na płynące od niego dobro, mądrość i wielką moc. Jest to ten sam moment połączenia się z Bogiem we własnej duszy, o którym pisze Karol Wojtyła w Pieśni o blasku wody, zachęcając do zagłębienia się we własne wnętrze, do poznania siebie, jednocześnie poddając się zbawiennej mocy Boga. Tę myśl wyrażają późniejsze słowa Jana Pawła II wygłoszone w Warszawie podczas Homilii w roku 1979:

Człowieka nie można do końca zrozumieć bez Chrystusa. A raczej: człowiek nie może siebie sam do końca zrozumieć bez Chrystusa. Nie może zrozumieć ani kim jest, ani jaka jest jego właściwa godność, ani jakie jest jego powołanie i ostateczne przeznaczenie ${ }^{5}$.

W literaturze motyw blasku jako symbolu boskości można znaleźć na przykład w średniowiecznym utworze Kwiatki świętego Franciszka nieznanego autora, co nie dziwi, ponieważ w dobie średniowiecza pisano głównie anonimowo - na chwałę bożą. Podczas widzeń, które ukazują się w tym utworze świętemu Franciszkowi, wszystko, co świętemu się objawia jest spowite światłem: ukazało mu się światło cudowne, otaczające świętego Franciszka; a w świetle tym ujrzał Chrystusa i Dziewicę Maryję, i świętego Jana Chrzciciela, i Ewangelistę, i ogromne mnóstwo aniołów. Innym przykładem wykorzystania tego motywu jest Makbet Szekspira, gdzie blask symbolizuje dobro i ochronę przed złem. Lady Makbet nie rozstaje się ze świecą, której światło dodaje jej otuchy, odgania złe myśli, demony czające się w wyobraźni, psychice, podświadomości. W obydwu przykładach blask, tak jak i w Pieśni o blasku wody ma znaczenie pozytywne, kojarzące się z Bogiem. Symbolizuje płynące od niego dobro, mądrość i wszechwiedzę. Dla mnie tytuł utworu - Pieśń o blasku wody - jest więc apoteozą, uwielbieniem Boga, a blask wody peryfrazą na jego określenie.

Kluczowym słowem Pieśni o blasku wody, które wiąże wszystkie zawarte w niej metafory i symbole w jeden sens, jest więc słowo „poznanie”. Działem filozofii zajmującym się relacjami między poznawaniem a rzeczywistością jest epistemologia. Karol Wojtyła przedstawił w utworze własną, filozoficzną koncepcję o odkrywaniu i poznawaniu świata metafizycznego: „tyle, tyle poznania znalazłam - ileż więcej niż dotąd! Znalazłam w odbiciu tej studni tyle pustej w sobie przestrzeni”. Koncepcję tę jako papież zawarł w swojej pierwszej, programowej encyklice Redemptor

\footnotetext{
${ }^{5}$ Jan Paweł II, Homilia wygłoszona podczas Mszy św. Na placu Zwycięstwa w roku 1979.
} 
Hominis ogłoszonej w marcu 1979 r. Mówi w niej o tym, że kluczem do odnalezienia się w świecie i odnalezienia siebie w sobie jest odkrycie miłości, którą utożsamia z Bogiem. Według Jana Pawła II, zaprosić Boga do swojego wnętrza znaczy zrozumieć, pokochać ludzi, świat i siebie samego, znaleźć swój cel i sens. Człowiek staje się wtedy źródłem miłości, którą automatycznie obdarza też innych ludzi i wszystkie inne istoty. Sam staje się życiodajną wodą:

Człowiek nie może żyć bez miłości. Człowiek pozostaje dla siebie istotą niezrozumiałą, jego życie jest pozbawione sensu, jeśli nie objawi mu się Miłość, jeśli nie spotka się z Miłością, jeśli jej nie dotknie i nie uczyni w jakiś sposób swoją, jeśli nie znajdzie w niej żywego uczestnictwa. I dlatego właśnie Chrystus Odkupiciel objawia w pełni człowieka samemu człowiekowi'.

To jest ów - jeśli tak wolno się wyrazić - ludzki wymiar Tajemnicy Odkupienia. Człowiek odnajduje w nim swoją właściwą wielkość, godność i wartość swego człowieczeństwa. Człowiek zostaje w Tajemnicy Odkupienia na nowo potwierdzony, niejako wypowiedziany na nowo. Stworzony na nowo!

Przekazem Pieśni o blasku wody jest przede wszystkim konieczność dobrej woli człowieka do zrozumienia siebie i zmieniania na lepsze. Człowiek musi sam zaprowadzić się do tej metaforycznej studni i zagłębić we własnym wewnętrznym świecie, poznać swoją wewnętrzną prawdę. Studnia w Pieśni o blasku wody pełni rolę łącznika pomiędzy światem zewnętrznym i wewnętrznym, pomiędzy człowiekiem a Bogiem. W głębinie studni kobieta odnajduje połączenie z Bogiem, oślepia ją Jego blask ukazany metaforycznie jako blask wody.

Studnia jest w utworze obrazem głębi wewnętrznego świata człowieka. Symbolizuje nieskończoność i niemierzalność z jednej strony tej pustki, którą nosi w sobie człowiek, z drugiej głębię Boga, ponieważ według Jana Pawła II tylko bezmiar Boga jest w stanie wypełnić bezmiar pustki w człowieku.

Motyw studni występujący w Pieśni o blasku wody budzi także skojarzenie z baśniami ludowymi, w których można go często spotkać. W bajkach magicznych pójście do studni zawsze uruchamia działanie sił nadprzyrodzonych. Otwór prowadzący do wód głębinowych okazuje się często drogą w zaświaty, przejściem do innego wymiaru. Zazwyczaj od momentu znalezienia się przy studni zaczyna się także przemiana bohatera. Znaną z nadprzyrodzonych mocy studni jest między innymi bajka Pani Zima autorstwa braci Grimm, w której uboga pasierbica gubi w studni wrzeciono, po czym do niej wpada, usiłując je wyciągnąć. We wnętrzu studni odnajduje drogę do innego, magicznego świata, rządzącego się własnymi prawami. Zostaje w nim doceniona, obdarzona bogactwem, dobrem i miłością.

${ }^{6}$ Jan Paweł II, enc. Redemptor hominis, s. 10. 
Studnia w literaturze pełni zatem najczęściej rolę medium. Jest łącznikiem z nadprzyrodzonym światem, a moment zetknięcia się bohatera ze studnią jest przełomem, który zapoczątkowuje odmianę życia. Pełni rolę inicjacyjną. W takim ujęciu studnia jest więc symboliczną drogą człowieka ku własnemu wnętrzu. W Pieśni o blasku wody podmiot liryczny przechodzi właśnie taką drogę ku swojemu duchowemu życiu. Po kontakcie ze studnią dokonuje się w nim przemiana. Studnia jest dla niego rodzajem medium prowadzącego do Boga. Kobieta łączy się z nim poprzez studnię pełną życiodajnej wody, co jest symbolem przejścia, otwarcia nowego etapu w życiu, osiągnięcia dojrzałości duchowej. Takie rozumienie studni wiąże się z jej symboliką w Piśmie Świętym, gdzie motyw ten występuje jako symbol wewnętrznego oczyszczenia, błogosławieństwa i daru życia.

Studnię odbieram także jako metaforę głębi wewnętrznego świata twórcy, który sięga do niej podczas pisania. Być może, Karol Wojtyła zadumał się nad rozległością swojej wewnętrznej przestrzeni, którą odkrywał w trakcie tworzenia. Sam, jako poeta, odnalazł w sobie poznanie, o którym mówi podmiot liryczny w Pieśni o blasku wody, a więc połączenie ze światem duchowym, z Bogiem. Z pewnością tworzenie pozwoliło mu lepiej zrozumieć samego siebie, wniknąć w głąb własnej duszy. W takim rozumieniu utwór jest nacechowany nieco autotematycznie. Wyraża zafascynowanie procesem tworzenia, który pozwala twórcy odkryć siebie, swój wewnętrzny świat, lepiej siebie poznać i zrozumieć. Jest to także refleksja nad pochodzeniem twórczej inspiracji, której źródło Jan Paweł II widzi w duchowości, w połączeniu z Bogiem, co łączy się z teorią pisma automatycznego, według której tworzenie jest procesem dokonującym się bez kontroli piszącego, mającym źródło w świecie nadprzyrodzonym.

W Pieśni o blasku wody pisanie wydaje się także procesem prowadzącym do lepszego poznania Boga, odkrycia go w sobie lub też postrzegać można je jako doskonalące człowieka na tyle, by mógł w sobie odnaleźć Boga. Przywołuje to na myśl słynny motyw lotu, stworzony przez rzymskiego poetę Horacego, który zapoczątkował myślenie o poecie jako o istocie na duchowo wyższym poziomie, unoszącej się ponad światem, wolnej od schematów, sztywnych reguł, co potem szczególnie upodobano sobie w dobie romantyzmu, wpadając przy tym w niebezpieczną skrajność. Przed Janem Pawłem II w taki sposób proces tworzenia utworu literackiego przedstawił polski, renesansowy poeta Jan Kochanowski w pieśni Kto mi dał skrzydła. Zawarł w tym utworze refleksję nad doskonałością Boga, przedstawiając Go jako życiodajne światło, jednocześnie pokazując, że poeta może poznawać Boga właśnie dzięki swojemu talentowi.

Dużo miejsca wewnętrznemu życiu poety poświęcił także w swoich utworach Aleksander Wat, który zawarł w swojej twórczości dramat dwóch wojen światowych. W utworze Sen Wat zawarł słowa: 
Jest we mnie wyspa

i niebo nad nią

i rzeka wokoło,

w których zobrazował życie wewnętrzne poety, który ma w sobie metaforyczną wyspę, czyli alternatywny świat, który pozwala mu skonfrontować się z samym sobą, poznawać siebie. Wokół tej wyspy płynie rzeka, żywa woda która jest dla niego natchnieniem do pisania i zgłębiania zakamarków własnej duszy, podobnie jak w Pieśni o blasku wody.

W utworze Jana Pawła II szczególną uwagę zwraca także motyw zwierciadła, który w literaturze i sztuce występuje bardzo często i w rozmaitych znaczeniach. Wykorzystał go, między innymi, Hieronim Bosch, ilustrując wspomniany już wyżej Stół na zamówienie Filipa II Habsburga. Dzieło przedstawia ilustracje siedmiu grzechów głównych i taki też nosi tytuł. Ilustracja pychy (superbia) przedstawia kobietę siedzącą tyłem, której szatan podaje lustro, kusząc by się w nim przeglądała i podziwiała swoje odbicie, co jest symbolem pychy, próżności, narcyzmu, które są uznawane za pierwszy grzech główny.

Ciekawe ujęcie motywu zwierciadła prezentują także baśnie, w których występuje on jako symbol obnażenia, prawdy. W bajce o królewnie Śnieżce macocha przegląda się w lustrze i w pewnym momencie okazuje się, że nie jest już najpiękniejszą kobietą w królestwie, ponieważ stała się nią Śnieżka - pasierbica przez macochę wzgardzona i okrutnie traktowana. Sądzę, że nie chodzi tutaj jedynie o piękno fizyczne, ale również duchowe. Śnieżka pojawia się w umyśle królowej jako wyrzut sumienia, którego za wszelką cenę pragnie się pozbyć. Lustro w obydwu powyższych przykładach jest, podobnie jak studnia, przedmiotem magicznym, który także jest czymś w rodzaju medium. Skłania bohatera do przyjrzenia się sobie, własnemu wnętrzu, postępowaniu. Zachęca do rozważań natury psychologicznej i moralnej. Ma zatem znaczenie podobne do tego, w jakim funkcjonuje w Pieśni o blasku wody, w której motyw zwierciadła występuje jako odbicie $\mathrm{w}$ wodzie. Podmiot liryczny dostrzega w lustrze wody swoje odbicie i zagłębia się w swoim wnętrzu. Zaczyna rozmyślać o swojej wewnętrznej pustce, która go przytłacza i przeraża, a więc zwierciadło pełni tutaj funkcję również symbolu obnażenia, odkrycia prawdy o sobie. Kobieta, będąca podmiotem lirycznym, wyraża pragnienie połączenia się z Bogiem. Prosi, by pozostał w jej duszy, by się w niej odbijał jak w zwierciadle, co automatycznie nasuwa skojarzenie z platonizmem. Zgodnie z platońską myślą, nasz materialny świat, który postrzegamy zmysłowo, jest odbiciem świata idei, który jest niematerialny, trwały i nieruchomy. Jest światem doskonałych bytów duchowych. Tak więc, kobieta w Pieśni o blasku wody chce odkryć w sobie odbicie tej trwałej, doskonałej idei jaką jest Bóg i prosi Go, by w niej pozostał, zagościł na dobre. 
Pieśn o blasku wody zachwyca głębią i wielowymiarowością. Skłania do filozoficznych refleksji nad sensem istnienia, tajemnicą bytu, niemierzalnością i złożonością świata. Najcenniejszą jej wartością jest jednak uniwersalność. To, że w kobiecie przychodzącej zaczerpnąć ze studni każdy człowiek może zobaczyć siebie, swoje życie, swoje duchowe potrzeby i pragnienia. Jan Paweł II nie buduje hierarchii bytów. Łączy człowieka z innymi istotami, podkreśla jego związek z przyrodą, co zawarł w słowach podmiotu lirycznego: „pragnę, byś pozostał jak w zwierciadle studni zostają liście i kwiaty z wysoka zdjęte”.

Obecna w utworze woda, żywioł powołujący życie na ziemi, jest jednocześnie metaforą życia duchowego, wewnętrznego bogactwa, którym obdarza Bóg. Rola wody jest zatem w utworze kluczowa. Jest symbolem równości, jedności wszystkich istot. Odbija się w niej blask - wizerunek Boga. W wodzie jest Jego tchnienie. Karol Wojtyła jako papież Jan Paweł II z pokorą i szacunkiem wypowiadał się na temat przyrody, tajemnicy bytu jako zamysłu Stwórcy.

Pieśn o blasku wody zachęca każdego do przyjrzenia się własnemu wnętrzu, do zrozumienia swojej duszy i zaproszenia do niej Boga. Zgodnie z myślą Jana Pawła II, Boża moc jest obecna w każdym życiu. Odbija się w każdej istocie niczym w zwierciadle, a człowiek różni się od innych ziemskich bytów jedynie posiadaniem wolnej woli. Do niego należy wybór, czy otworzy się na energię Boga, na poznanie pozarozumowe, a więc czy duchowo dojrzeje, czy pozwoli swojemu umysłowi rozwinąć skrzydła. Na przeszkodzie człowiekowi stoi jedynie lęk. Jan Paweł II często mówił o tym, że do duchowego szczęścia konieczne jest pozbycie się lęków, które są przyczyną nieszczęścia: „Nie lękajcie się. Otwórzcie, otwórzcie na oścież drzwi Chrystusowi!"” - te piękne słowa kierował do ludzi wszystkich kultur i religii. Jedną z najważniejszych wartości jego pontyfikatu było przełamywanie granic między ludźmi, łagodzenie różnic poglądowych, religijnych, kulturowych i powstających na ich tle napięć poprzez działalność na rzecz ekumenizmu, ale także przez odbywanie licznych pielgrzymek, podczas których łączył się z ludźmi i ludzi ze sobą nawzajem. Swoim nieszablonowym zachowaniem i otwartością pokazywał, że mieć Boga w sobie znaczy mieć w sobie Wolność... Wolność od napięć, lęków, podziałów, od nienawiści, którą ludzie generują wobec siebie nawzajem, a która w konsekwencji uderza w nich samych. Jan Paweł II ukazywał Boga jako uniwersalną energię. Rozmawiał z przedstawicielami innych religii, pokazując, że wszystkie są ze sobą w gruncie rzeczy tożsame. W każdej z nich chodzi o odkrywanie i wielbienie tego samego Stwórcy, tylko odmiennie w różnych kulturach pojmowanego.

${ }^{7}$ Jan Paweł II, Homilia wygłoszona 22 października 1978 roku podczas Mszy św. na rozpoczęcie pontyfikatu. 
W Pieśni o blasku wody Bóg ukazany jest uniwersalnie i wielowymiarowo. Jan Paweł II nie nadaje mu konkretnego kształtu ani miejsca. Ukazuje go jako blask, jako wodę i jako rośliny, a więc jako życie, ponieważ nie byłoby życia bez światła, wody i tlenu. Ukazuje Boga także w jako energię drzemiącą w człowieku, która potrzebuje tylko zachęty, odrobiny dobrej woli, by się rozbudzić i poprowadzić człowieka ku szczęściu.

\section{Abstract \\ Discovering God. Interpretation of A Song about the glow of water.}

The Song of the Glow of Water is a piece, which John Paul II created in 1950, still as Karol Wojtyła. It is full of reflections on the extraordinary and life-giving nature of water, the element which the author identifies with God. The piece is a philosophical analysis of the complexity of the world as well as the external and internal human life. In it, the author reflects on spiritual needs, as well as personal and independent discovery of God by man. It is also a song about getting to know the mystery of Being. In A Song of the Glow of Water, John Paul II connects man with other beings, emphasizes his relationship with nature, which gives the work a universal and timeless dimension.

Keywords: water, inner life, discovering God, light, cognition, spirituality, being, universality 